\title{
HISTORY AND ORIGIN OF PUBLIC ECONOMICS
}

\author{
Dr. C. Vasudevan ${ }^{* 1} \mathbb{\Delta}$ \\ ${ }^{* 1}$ Assistant Professor, Department of Economics, Guru Nanak College, Chennai-42, India
}

DOI: https://doi.org/10.29121/granthaalayah.v8.i8.2020.772

Article Type: Research Article

Article Citation: Dr. C. Vasudevan. (2020). HISTORY AND ORIGIN OF PUBLIC ECONOMICS. International Journal of Research GRANTHAALAYAH, 8(8), 124-131. https://doi.org/10.29121/granthaa layah.v8.i8.2020.772

Received Date: 15 July 2020

Accepted Date: 25 August 2020

Keywords:

Public Economics

Objectives

Public Sector

General Equilibrium

Taxation

Asymmetric Information

\begin{abstract}
History and origin of Public Economics Presented as the evolutionary nature of its disciplinary interest to for student curriculaum and a method of analysis for Govt. Policy doiers. The subject matter of this article has fully involved to discuss from its history and origin from classical periods to its in modern times. Further this article explained the nature and characteristics of public economics in collaboration, as a method of analysis of many dominant issues like externalities, market failure and distortions effects is to be as subject of studies in its growth.
\end{abstract}

\section{INTRODUCTION}

Public Economics is a fairly recent innovation. The Journal of public economics published its first issue in 1972. The field of public economics amalgamates two broad branches of economics. ie., welfare economic theory and Public Finance. The main results of welfare economic theory relying on efficiency theorem to on impractical lumsum redistribution for characterizing almost Pareto efficient allocation. It provides a fair discussion of welfare measurement, externalities, and marginal cost pricing. It also attempted to make ethical pronouncement without value judgment (Hammond, 1990). On the other hand the other branch was called Public Finance was about to observe various measure of tax incidence. But it never provides theoretical foundation to understand completely what the role of tax systems to be followed. The amalgamation of these better of two branches inclined into new discipline we called Public economics has done much to benefit of both.

Public economics has studied the government function under various issues and how its policies to be effective in the economy. It considers how the choices of the government are made and how they can improve the economic efficiency. Public economics also investigates the extent to which it is possible for the government to influence the distribution of income and wealth and how this is desirable. In undertaking these tasks public economics is draw upon influences from many areas of economics. It gained a great deal by borrowing ideas from

(C) 2020 The Author(s). This is an open access article distributed under the terms of the Creative Commons Attribution License, which permits unrestricted use, distribution, and reproduction in any medium, provided the original author and source are credited. 
other fields. Such as stabilization policy from macro economics, maximization principles from welfare economics with Pareto efficiency criterion to the provision of public goods provision, and incidence of taxation from international trade. (Atkinson 1987). This is reflected in the diversity of its subject matter which ranges from the traditional studies of effects of taxation to public choice explain the functioning of the government. Thus there are many sides of public economics.

On the extension of public economics it deals with issues of degree of progression for the income tax, the choice between direct and indirect taxation, the provision of public goods and pricing for public enterprises. Thus public economics that is to say the study of public intervention in the economy have emerged from public finance in the 1950s to reach its autonomy, at the beginning of the seventies, with in particular the creation of Journal of public economics in 1972. (Laffont 2002) Public Economics had received many of her Nobel prizes winners emphasizing with for their contribution in public policy decisions making over the years in its field. The winners of the Nobel Prizes among them are, James Mirrlees, William Vickery, Samuelson, Arrow, Becker, Friedman and Lucas and Coase.

\subsection{THE CHARACTERIZATION AND SCOPE OF PUBLIC ECONOMICS}

In a broadest interpretation of public economics is the study of economic efficiency, distribution and government economic policy. The subject encompasses topics as diverse as responses to market failure, due to the existence of externalities, motives of tax evasion, and the explanation of bureaucratic decision making. In order to reach into all this understanding, public economics has developed from its initial narrow focus upon the collection and spending of government revenues to its present concern with every aspect of government intervention in the economy. Public economics attempts to understand how the government makes decisions and what decisions it should make to involve theoretical development of the subject. Determining what decisions should be made is to refer studying the effects of the alternative policies that are available and evaluating the outcomes to which they studied these aspects are referred throughout this text. Public economists then can be critized for having the long neglected the progress that has been made elsewhere in economics.

\subsection{THE MAIN OBJECTIVES OF PUBLIC ECONOMICS}

- Public Economics is for the study of Public policy.

- It deals upon taxation, public expenditure, Provision of Public Goods, Public dept management and other fiscal issues in the problems of federal forms of the government.

- It main focuses are market failure, externality, transaction cost, demand revealing process, optimal of taxation and with other similar problems involved.

- It main emphasize is on how to avoid market failure and the determination of optional social security policies.

- This characterization reflects an extension of the scope of Public economics from its initial emphasizes upon the collection and disbursement of government revenues to its permanent concern with all aspects of government economic intervention.

\subsection{PUBLIC ECONOMICS AND ITS CONTRIBUTORS}

The study of public economics has its own history and a long tradition. Example Ricardo (1817), Cournot (1838), Edgeworth (1925) Pareto (1909), Vickery and Meade (1971), Samuelson (1954,1959) and Buchanan (1950). It developed out of the original political economy of Mills and Ricardo through the public finance tradition of tax analysis into Public Economics. Now it has returned to its roots with the development of the new political economy. From the inception of economics as a scientific discipline public economics has always been one of its core branches of economics. The explanation for why it has always been so central now is that the formulation that it provides for practical policy analysis. This always have been motivated of public economics even issues under studies have analytical methods employed over time.

Coase a leading economists had set out a conceptual approaches to the study of externalities and transaction cost that has become an implicit part of the methodological baggage that carried around by policy economics. (Boadway 1997). Buchanan was in part of responsible for institutions in public sector decision making for instituting 
that politicians, bureaucracies and voters are human being with human motives. Mirrlees and Vickery approached to the theory of economic policy on the ground on the importance of imperfect information as a constraint on public policy have changed the very nature of public economic research and of its implications for economic policy and the role of government. (ibid).

\subsection{THE ROLE OF PUBLIC SECTORS IN PUBLIC ECONOMICS}

Musgrave (1959) monumental work "Theory of Public Finance" found the role of public sectors revolved around the notion of market failure especially arising from the free rider problems of public goods. The efficiency branch of government was changed with correcting market failures by providing public goods, implementing Pigovian taxes and subsidies and ensuring competition. There was a stabilization branch responsible for implementing the Keynesian fiscal issues policies to manage.

The theoretical construction to policy analysis also highlights its value and provides a test by its relevance. One of the challenges of public economics is that much of the subject area is still in its infancy considerable work still need to be done (Myles 2001).The subjective matter of Public economics is concerned with the convenient position as the most instrumental division is between that of determining the effects of alternative policies and that of the optimal policy. The division represents the distribution between the exercise in positive economics involved in calculating the change the equilibrium caused by introduction of policy and the nornative exercise evaluation (ibid). To achieve its first objectives requires a theory that describes how economic agents charge their actions and how there actions are offered by in policy. The individual agent must then be combined to form in economy and a theory of equilibrium provide for this economy. The exercise and evaluation nature of these policies respondents on application of normative ideas on economics. This success of public economics has hereby followed the systematic application of these methods.

\section{THE THEORETICAL FOUNDATION OF PUBLIC ECONOMICS}

The theory of public economics is described since the periods of Adam Smith till date. The theory of public economics has since built upon by developments in micro economics, macro economics, general equilibrium theory, game theory, welfare economics, and fiscal doctrine of government role and Keynesian formulation of interactive process. One of its basic characteristics is the use of duality techniques to allow problems to be pursued in the manner most amenable to solution. (ibid). These techniques permit optimization exercises to be processed in term of natural choices variables. In this context the work of many economists has become fundamental importance to be built in the theory of public economics. Accordingly, the general equilibrium theory provides a rigorous foundation for the policy analysis.

General equilibrium analysis of policy captures both the direct secondary effects of policy. These underlying methods of duality and general equilibrium provide the cohesion of to what at first glance may appear to be a number of disparate topics. The main theoretical frame work has been increasingly adopted in modern public finance called public economics is to be a competitive general equilibrium model set out definitely in Arrow-Debreu (1959) theory of values. The model albit in highly simplified form has been widely applied to the question of incidence of normative treatment. Recent theoretical work concerned the idea of with non-convexities, imperfect competition, and disequilibrium behavior all it has brought out the special nature of many of its results and suggested for the policy programes of the governments. The development of Public Economics is limited then in classical way of formulation by the short terming of competitive equilibrium analysis. The dominant setting of analysis of public economics has within the mixed economy so that individual decisions are reported. The design of policy can then be interpreted as the manipulation of individual choices of policy parameters so as to arrive at equilibrium. This makes the results of the studies applicable to countries of most developed economics and concerns with the present ascendency of such a form of economic organization. 


\section{HISTORY AND ORIGIN OF PUBLIC ECONOMICS}

\subsection{PUBLIC ECONOMICS IN CLASSICAL TIME}

The theory of Public expenditure, equity in taxation, efficiency in fiscal policy are main focuses of classical economist start from Adam Smith (1776), Ricardo, J.S. Mill, Dupit, Edgeworth, Wicksell and Pigou. The history of Public Economics called itself the fiscal doctrine in time to time perhaps more than that of are other aspects of economics are carries a particular fascination on the one hand and it reflects the advances of analytical economics and enrichment of tools box, to use Joseph Robinson's terms on the other hand which may then applied to the solution of fiscal problem ( Musgrave 1985). The close linkages between general and fiscal then is most evident for the analysis of tax incidence, which at each stage reflects the prevailing theory of price and distribution. The analysis of tax equity was affected profound by the growth of utility theory. (ibid)

The cooperation of public sector, as developed by the classical economists is seen in the context of natural order, which calls for reliance and non interference with the market. Public provision and taxation for its finance is called for only where exceptional circumstances demand it. A definition of this circumstances is attempted but the tools for precise analysis were still lacking. Thus, an essential feature of classical economists approach is that the economics of expenditure and taxation are preserved as separate issues.

Adam Smith sets out the "Obvious and simple system of natural liberty that will establish itself of its own accord" once government restraints are withdrawn. (Quoted in Musgrave 1985) He emphasized these duties of government functions such as duties of protection, Justice and public works. Having stated these three functions Smith (1759) examines each in detail. Smith in his theory of moral sentiments he presents an extremely complex and subtle structure of human interaction. Comparing a multiplicity of forces and motivations individual guided by the invisible hand are led to interact so as to produce a socially desirable outcome. Smith also recognized that market failure occurs in the provision of certain public goods (Musgrave 1985).

According to the David Ricardo (1817) the idea of government intervention is to be presented as "that the very best of all plans of finance is to spend little, and the best of all taxes is that which is least in amount". (ibid) Ricardo dealt with the effects of taxation on the private sector only. There is nothing to be found on public expenditures in his treaties (ibid).

Other classical economist like J.S. Mill (1848) viewed society through quiet different windows. For his laizesfair should be the general practice, every departure from it unless required by some great good is a certain evil (ibid). He found the most important instances where departure is called for. He emphasized two types of instances of government function that one is ordering that called law and order, links to property protection. The other function he means utility of certain products, elementary education, undertake irrevocable contracts and regulations. Mill then recognized implicitly the existence of a prisoner's dilemma and free rider problem condition which require public intervention, (Ibid).

Thus the "the traditions of British authority from Adam Smith on viewed the market as the rule and the public sector as the exemption, needed to step in if and where a Specific market Failure occurs" (Ibid) Under this the British fiscal theory emerged from the background of the Lockean model, that a society is based on individual entitlements and free exchange, guided by the beneficent rule of an invisible hand.

Wagner (1883) a leading exponent of fiscal theory in his time formulated his law of expanding state activity based on technical factors increased density and urbanization as well as growing acceptance of social policy objectives in fiscal affairs. There are German authorities, in 1880s and the Austrian and Italian writers who emphasized a new doctrine which was then given the preferences of individuals and welfare maximization by having each equate marginal utility with price. This basic efficiency rule applies to both public and private goods. Other than private goods in the case of public goods the critical feature of indivisibility requires the same quantity to be available to all consumers. Musgrave (1985) pointed out that the Marginal utility of the same quantity differs among them, the equating process calls for different prices to be changed. Thus, benefit taxation becomes the "Supreme law of the fiscal economy".

Wicksell other leading writer (1896) have recognized the free rider problems. He says that free rider behavior is as important with assumption of altruistic and omnipotent behavior. The real problem as he saw it was to design a practical process which will approximate an optimal outcome. Wicksell emphasized rule of approximate, unanimity, minority rights and normative approach to voting models. Next to Wicksellian formulation, Eric Lindahl's 
emerged to pointed out that with his doctoral dissertation on "interaction solution" to settle the quantity to be supplied equal to the value of the marginal utility which he derives with the sum of the two tax prices adding up to the cost of the product. Lindhal schedules called as "Pseudo demand curves" referred by Samuelson (1954) later. Lindhal solution of interaction is reached only on the assumption of "equal bargaining power" is two consumerbased society in assumption. Latter he expanded upon the political setting in which the budget determination occurs. The concept of Lindhal price and its initial demand and supply presentation has remained his key contribution.

In 1920s the classical tradition of public economics was grounded with some of its perspectives. Pigou's (1920) Economics of welfare introduced new perspectives. This perspective emerged from the concept of externalities central to the Pigovian distribution between social and private net product. According to the Pigouvian perspectives the private net product measures the internalized cost and benefits which are recorded in market price. It was not until 1939 that the Pareto efficiency doctrine were under discussion. Public Economics discussion with Pareto efficiency rule was then have a great important in the growth of Public Economic Literature and welfare Economics. Samuelson model $(1954,1955)$ addressing the implications of indivisibility and joint consumption for Pareto efficiency. Samuelson says that the determinants a set of optimal solutions involving a mix of output between private and social goods and a division of the former among consumers. In the literature of fiscal theory a rigorous interaction of social goods in to the conditions of Pareto efficiency were addressed well. The analytical neatness and abstract formulation of Samuelson's model meets the pure sprit of Paritian welfare economics and such that invited the attention of economics theorists. The great realism of the Wicksellian approach thus offered a more workable stepping stone to the problems of budget policy (ibid).

\subsection{NATURE AND GROWTH OF PUBLIC ECONOMICS IN THE MODERN TIMES}

Modern Public Economic is to be made by economic models. Models are used for analysis because the possibilities for experimentation are to be limited. Each model is in intended to be simplified description of the past of the economy, that is relevant to the analysis. Capturing the implication of complete behavior in a community manner is one of the key skills of successful economic models. The method of policy analysis in public economic is then to be building a model of the economy and to find its equalization. Policy analysis is undertaking by determining the effect of a policy by training the way in which it carry the equilibrium of the economy relative to some status quo. Alternative policies are contracted by comparing the equilibrium to which they it leads. Modern public economics was then born from taking into account of more of less explicitly the informational constraints of the state in its role of production, allocation and distribution of resources.

\subsubsection{PUBLIC ECONOMICS WITH ARROW-DEBREU MODEL}

Arrow - Debreu has dealt the second welfare theorem. Arrow -Debreu formulation of theoretical mode under convexity assumptions on the production sets as a Pareto optimal allocation of resources can be decentralized as a competitive equilibrium eventually offer a redistribution of initial resources through lump sum taxes. The second welfare theorem assumes the convexity of production sets which is problematic in public economics.

Starrett (1972) shows that the non-convexity of the production sets can extended to include pollution rights in the cure of negative externalities. It has been understand that for numerous public services, the non-convexity of production sets (the natural monopoly hypothesis) seem, to be the rule. Pricing at marginal cost with public funding of deficits by lump sum taxes, suggested by Hotelling (1938). Guesnerie (1975) produces some distributions of initial resources are incompatible with Pareto efficiency even if those goods are priced at marginal cost. Beato and Mascolell (1985) shows that, in the absence of lump sum taxes, even productive efficiency violated. This pricing at marginal costs does not allow in general equilibrium of the decentralization of price to the optima. (Laffont 2002).

\subsection{PUBLIC ECONOMICS IN PARARADIGAM SHIFT}

It has been said that Public Economics had been reborn 25 years after the work of Ramsey (1927) and 15 years after that of Hotelling (1938). More visible developments soon followed in particular by Samuelson (1954) on Public goods. The marketing of the field is often associated with the contribution of Diamond and Mirrless (1971) on "Optimal taxation and Public Production" which demonstrated that the possibility of approaching within a single 
unified frame work where there areas of central interest about on taxation, public sector pricing and public goods. There is also of addition of productive efficiency. (Dreze 1995)

Presently Public Economics has now emerged as a full text and curriculum to qualify as a field of economics on par with labors, international trade, industrial organization, or development. Public Economics as in terms is now displacing its respectable predecessor "Public Finance" and basically choking of welfare economics as a separate field (ibid). The term "Public economics" has now been gained acceptance to designate as "the economics of public sector" as proposed by Atknison and Stiglitz (1980) in their text book or the "study of governments effect" on the economy as proposed by Auerbach and Fieldstein (1985) in their hand book. In the new Palgrave dictionary by Kolm (1987) defined the origin of the term is dated to his "Fondements de l" Economie Publique" published in 1964. Richard Musgrave (1987) entitled "Public finance" and notes that concern with "Finance may well be the oldest branch of economics" going back to antiquity. Some essentials of the modern agenda like the criteria of public expenditure and public sector pricing had pioneered in the nineteenth century by Jules Dupit. (ibid).

The transition from Public finance toward Public economics was held around 1950. It refers specifically to the two contributions that is the theory of optimal public sector pricing and of optional taxation which the two topics were central to the public economics (ibid). The methodological core of this work consists deriving general qualitative formulae, within the standard Walras-Arrow-Debreu general equilibrium model extended to encompass public goods and taxation. (ibid). Further modeling, assumptions, about the economy of the policy instruments are typically needed to deal with such issues as corporate taxes, inheritance taxes, the tax base, capital income taxation and so on. The developments of Public Economics thus become a field of enquiry in different aspects.

Vickery $(1952,1955)$ has investigated the marginal cost pricing. In his formulation he observed that the distortions that in the market was associated in which the with realistic methods of collecting municipal taxes. In contrast to Vickerry, Engineers in France implemented their own suggestions, which they did to demonstrate the system of "peak load pricing" was directly inspired by original research. By Boiteux (1945) on peak load pricing realizing extensively the mathematical investment models of Maurice Allais (1948) who advocated rates proportional to marginal costs. Boiteux in his paper in (1956) he states that and solved it the general problem of characterizing Paereto optimal production and tariffs for public monopoly subject to budget balance, under the assumption that the economy is otherwise competitive and income effects are compensated. This was definitely the most general and rigorous statement of a public decision problem until then (ibid). The work of Boiteux and his colleagues had the remarkable prosperity of spanning the whole spectrum from practical problems to the most abstract theorizing of the day. Now the problems studied by Vickerry and Boiteux arise from the non-convexity of production sites in a situation with high fixed costs and increasing return to scale. Guesnerie (1975) and then Brown and Geoffrey (1979) two authors in terms of aggregate production set reveal the possibility to violates Pareto efficiency unless there is a representative consumer. Beato and Mas-Colell (1985) reveals that the possibility in the absence of specific, lump-sum transfers. Every demonstrated of equilibrium violates aggregate productive efficiency - let alone overall Pareto efficiency (ibid)

Another area of fundamental reliance to public economics where abstract theorizing. The incentives computability, information asymmetry is essential typically belong to the sphere of public economics because market mechanisms do not provide the required incentives. A Standard illustration is that the "free riders problems" in choosing an optimal provision of public goods, namely level where the marginal costs of provision is equal to the sum of the so-called "marginal willingness to pay" of users. If the changes are based on reported preferences then there is an incentive to underreport and conversely it the changes are unrelated to reported preferences. (ibid) Jean Dreze and Stern (1985), Starrett (1985), Layard (1972) and Glarister who had been done on cost benefit analysis to the centre stage of public economics.

The unifying process of the general equalization model, extended to public goods, and second-best analysis, where neo classical and neo Keynesian schools still compete for the centre stage. Moreover, neither school operates yet within a methodology easily integrated with that of Public economics. There are other authors by Dierker, Guesnerie and Nevefeinad (1985) in Econometrica published a theory of general equilibrium developed for economics with non convex production set, where firms follow well defined pricing rules. In 1988 issue of the Journal of mathematical economics were devoted to existence process of equilibrium in non-convex economics, under alternative formulations of the assumption that the marginal cost pricing entails bounded loses at normalized prices.

Vickrey (1987) writing on "Marginal and Average cost pricing" advocates prices reflecting continuously (in time) short run social marginal cost. Masse (1987) writing on "Public Utility Pricing" advocates prices reflecting long - run marginal cost. The theory of "equilibrium in supply functions" studied in particulars by Klemperer and Meyer 
(1989). The new practical developments thus force economists into new theoretical developments in an equilibrium of State -contingent contracts, priority service contracts of supply functions. These analyses are still in infancy (i bid). Models of Metropolitan suburbanization for instance, aim at integrating all these elements. Proper tools thus included theories of local public goods, clubs and fiscal-federalism which are close to the centre stages of public economics. (ibid)

But more remote association can help as exemplified by the formal analogy between the non-convexity arising in economics with level of public goods and in economics with incomplete asset markets which have been the subject of extensive theoretical research. (Dreze 1974, Starrett 1988) A field like public economics can potentially a useful role in transferring knowledge across boundaries of specialization. But only if application from health and transportation of economics, urban and public choice economics and other are included in standard course of work to text books and hand books.

The real problems encountered in these and many other areas after scope for the general equilibrium mathematical analysis of second-best policies. At the far end of the spectrum is in abstract modeling of economics with non-convex technologies or uncertainty and incomplete markets.

\section{PRESENT SCENARIO IN LITERATURES OF PUBLIC ECONOMICS}

\subsection{ASYMMETRIC INFORMATION}

Asymmetric information is another major breakthrough in the literature of public economics. It is identified that some precursors are Vickry (1945), Mirrlees (1971). The core Mirrlees modeling is the asymmetric information concerning the agents intrinsic productivities. Marginal rate of substitutions between income and leisure is a monotonic function of the intrinsic productivity of the agent. The economists agree upon the week input of this work on economic policy.

The general equilibrium framework chosen by Diamound and Mirrlees (1971) to provide a general theory of linear taxation have had a more practical influence. The informational constraints amount here to the linearity of income taxation and of excise taxes. Then the problem of optimal taxation appeared clearly as the problem of the optimal set of tax base and tax rates, given the difficulties of observing economic transactions and given other asymmetric information suffered by tax authorities. The general results from second-best optimal taxation addressed by Guesnerie (1995) remained a meager and had to be relayed by an approach using simulations of calibrated general equilibrium model in the 1990s.

\subsection{FREE RIDER PROBLEMS AND REVELATION PRINCIPLE}

Public Economic has now known a particular excitement in the seventies, when stunting with the articles of Groves (1973) and Clarke (1971) introduced new solutions and were prepared to solve the true sides problems namely the problem by how to decide the level and funding of public goods. However, the empirical relevance of these solution become debatable the achievements realized in incentive theory by Green and Laffont (1979), Aspremont and Gerard-Varet (1979) has played and important role for other fields of economics which have imported those tools in the 1980s and 1990s.

Revelation Principle which establishes the validity of centralized approaches to public decision making even in the presence of adverse solution and moral hazard. It provides normative framework alternative to the ArrowDebreu model when the state suffers from asymmetric information. The notion of incentive compatible Pareto optimum i.e. an allocation which maximizes the Pareto conditions under incentive constraints has emerged as the new criterion of economic feasibility which allows us to compare institutions in more realistic fashion. Today public economics continues its progression by relaxing implicit and explicit assumptions of underlying the regulation Principle.

\section{CONCLUSION}

The history and origin of public economics here generally narrates its overall historical development and its scope, objectives, characterization with new paradigms shift in the recent years. This work also entitled the 
development of the subject matter and its more califare and structural terms of dealings over the periods from Adam Smith to present literatures covering. Thus, public economics as a subject emerged to be the topic of present analysis. Its methods and other covering issues still needs to grow to the policy management of subject matter to the need for present time.

\section{SOURCES OF FUNDING}

This research received no specific grant from any funding agency in the public, commercial, or not-for-profit sectors.

\section{CONFLICT OF INTEREST}

The author have declared that no competing interests exist.

\section{ACKNOWLEDGMENT}

None.

\section{REFERENCES}

[1] Atkinson, A.B., and Joseph E.Stiglitz, (1987), Lectures in Public Economics' McGraw-Hill, London.

[2] Beato, Paulina and Andreu Mas-Colell (1985), "On Marginal Cost Pricing with given Tax Subsidy Rules", Journal of Economic Theory, December, No.37.

[3] Boadway Robin, (1997), "Public Economics and the Theory of Public Policy", The Canadian Journal of Economics, Vol.30, No.4.

[4] Dreze, J.H., (1995), "Forty Years of Public Economics", Journal of Economic Perspective, Vol.9 ,No.2.

[5] Hammond, P.J., (1990), "Theoretical Progress in Public Economics: A provocative Assessment", Oxford Economic Papers, March, No.42.

[6] Laffont, Jean Jacques, (2002), "Public Economics Yesterday, Today and Tomorrow", Journal of Public Economics, No.86.

[7] Musgrave, R.A., (1985), “A Brief History of Fiscal Doctrine, Hand Book of Public Economics”. Vol. I, edited By A.J. Auerbach and M. Fieldstein, Elsevier Science Publishers, North Holland.

[8] Myles, G.D., (2001), Public Economics, Macmillan Publishers.

[9] Stiglitz, J.E., New Perspective on Public Finance: Recent Achievements and future challenches, Journal of Public Economics. 